\section{Expression Analysis of BMPR1B, BMP15, GDF9, Smad1, Smad5, and Smad9 in Rams with Different Fecundity}

\author{
Weihao Chen ${ }^{1,2}$, Zhilong Tian², Lin $\mathrm{Ma}^{2}$, Shangquan $\mathrm{Gan}^{3}$, Wei Sun ${ }^{1,4, *}$ and \\ Mingxing Chu ${ }^{2, *}$ \\ ${ }^{1}$ College of Animal Science and Technology, Yangzhou University, Yangzhou 225009, \\ China \\ ${ }^{2}$ Key Laboratory of Animal Genetics, Breeding and Reproduction of Ministry of \\ Agriculture, Institute of Animal Science, Chinese Academy of Agricultural Sciences, \\ Beijing 100193, China \\ ${ }^{3}$ State Key Laboratory for Sheep Genetic Improvement and Healthy Production, \\ Xinjiang Academy of Agricultural and Reclamation Sciences, Shihezi 832000, China \\ ${ }^{4}$ Joint International Research Laboratory of Agriculture and Agri-Product Safety, \\ Ministry of Education, Yangzhou University, Yangzhou 225009, China
}

\begin{abstract}
A B S T RA C T
To elucidate the tissue expression levels of BMPR1B, BMP15, GDF9, Smad1, Smad5, and Smad9 genes in rams with different fecundity, quantitative real-time polymerase chain reaction was used to investigate the expression level of six genes in the brain, cerebellum, hypothalamus, pituitary, testis, epididymis, vas deferens, and adrenal gland in high fecundity (Small Tail Han sheep) and low fecundity (Sunite sheep) rams. The results were as follows: BMPR1B, GDF9, Smad1, Smad5 and Smad9 were expressed in all selected tissues, but $B M P 15$ was specifically expressed in the epididymis. Further study indicated that the expression of BMPRIB in the brain, hypothalamus, pituitary, epididymis, and adrenal gland was significantly higher in Sunite sheep than in Small Tail Han sheep $(p<0.05, p<0.01)$; the expression of BMP15 in the epididymis was significantly higher in Sunite sheep than in Small Tail Han sheep $(p<$ 0.01 ); the expression of $G D F 9$ in the cerebellum and vas deferens was significantly higher in Small Tail Han sheep than in Sunite sheep $(p<0.05)$; the expression of GDF9 in the adrenal gland was significantly higher in Sunite sheep than in Small Tail Han sheep $(p<0.01)$; the expression of Smadl in the brain and adrenal gland was significantly higher in Small Tail Han sheep than in Sunite sheep $(p<0.05)$; the expression of Smad1 in vas deferens was significantly higher in Sunite sheep than in Small Tail Han sheep $(p<0.01)$; the expression of Smad5 in the adrenal gland was significantly higher in Small Tail Han sheep than in Sunite sheep $(p<0.05)$; the expression of Smad 9 in the brain and epididymis was significantly higher in Sunite sheep than in Small Tail Han sheep $(p<0.05, p<0.01)$; and the expression of Smad9 in the cerebellum and hypothalamus was significantly higher in Small Tail Han sheep than in Sunite sheep $(p<0.05)$. This is the first study to systematically analyze the BMPR1B, BMP15, GDF9, Smad1, Smad5, and $\operatorname{Smad} 9$ genes' tissue expression pattern in rams.
\end{abstract}

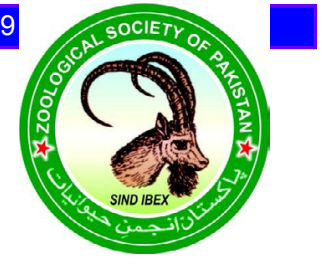

CrossMark \&cilickor updates
Article Information

Received 26 February 2019

Revised 11 May 2019

Accepted 11 June 2019

Available online 06 May 2020

Authors' Contribution

WH-C, ZL-T, L-M and SQ-G designed the experiments and analysed the data.

WH-C and W-S wrote the manuscript.

MX-C supervised the research and

approved the experiment.

Key words

Ram, BMPR1B, BMP15, GDF9, Smad,

Tissue expression.

\section{INTRODUCTION}

$\mathrm{L}$ ambing is one of the most economically important traits of sheep, being closely related to the economic benefits of sheep breeding. The major genes related to the prolificacy of sheep have received much attention from researchers since the 1980s (Tang et al., 2018). To date, three major candidate genes for the prolificacy of sheep have been found: bone morphogenetic protein receptor $1 \mathrm{~B}$

\footnotetext{
Corresponding authors: mxchu@263.net; dkxmsunwei@163.com 0030-9923/2020/0005-1665 \$ 9.00/0 Copyright 2020 Zoological Society of Pakistan
}

$(B M P R 1 B)$, bone morphogenetic protein 15 (BMP15), and growth differentiation factor-9 (GDF9) (Pan et al., 2018).

$B M P R 1 B$ is the first major candidate gene found to be related to the prolificacy of sheep (Shokrollahi et al., 2018) and possesses a mutation (A to G), known as FecB, which results in one amino acid substitution ( $Q$ to $R$ ) increasing the ovulation rate of Booroola ewes (Montgomery et al., 1994). The FecB mutation has an additive effect on ovine ovulation number and litter size, so that one copy of the FecB mutation can increase the ovulation number by $1.3-$ 1.6-fold and the litter size by $0.9-1.2$-fold, and two copies by 2.73 and 1.1-1.7, respectively (El-Seedy et al., 2017).

$B M P 15$ also known as growth differentiation factor9B (GDF9B), and $G D F 9$, which both belong to the 
transforming growth factor- $\beta$ (TGF- $\beta$ ) superfamily and are recognized as major candidate genes for the prolificacy of sheep-were found to regulate the growth and differentiation of follicles, the secretion of reproductive hormones, and the growth of germ cells (Belli et al., 2018). To date, Fec $X^{\mathrm{I}}, \mathrm{Fec}^{\mathrm{H}}$ (Galloway et al., 2000), Fec ${ }^{\mathrm{G}}$ (Hanrahan et al., 2004), FecX $\mathrm{X}^{\mathrm{L}}, \mathrm{FecX}^{\mathrm{B}}$ (Bodin et al., 2007), Fec $\mathrm{X}^{\mathrm{R}}$ (Monteagudo et al., 2009), Fec $\mathrm{X}^{\mathrm{Gr}}$, $\mathrm{FecX}^{\mathrm{O}}$ (Julie et al., 2013) and FecX $\mathrm{X}^{\mathrm{Bar}}$ (Lassoued et al., 2017) mutations have been found on the sheep BMP15 gene; they strong affect the ovulation rate and prolificacy, similar to the effect of G1 (Wang et al., 2018), G4 (Alam et al., 2018), G6, FecG ${ }^{\mathrm{F}}(\mathrm{G} 7)$ (Våge et al., 2013), $\mathrm{FecG}^{\mathrm{H}}(\mathrm{G} 8)$ (Shafieiyan et al., 2013), FecG ${ }^{\mathrm{E}}$ (Silva et al., 2011), $\mathrm{FecT}^{\mathrm{T}}$ (FecI) (Braun et al., 2003), FecG ${ }^{\mathrm{V}}$ (Souza et al., 2014), $\mathrm{FecG}^{\mathrm{T}}$ (Nicol et al., 2009), and FecG ${ }^{\mathrm{SI}}$ (Mullen et al., 2014) mutations on the sheep GDF9 gene.

Many studies revealed that the prolificacy of sheep is closely related to bone morphogenetic proteins (BMPs), BMP receptors (BMPR), and Smads, a downstream signaling molecule of the TGF- $\beta /$ Smad signaling pathway (Lin et al., 2018). Members of the BMPs initiate signaling from the cell membrane by interacting with two distinct serine/threonine kinase receptors. Ligand binding induces the formation of a complex in which the type II receptor phosphorylates and activates the type I receptor. This protein then propagates the signal by phosphorylating the Smad proteins such as Smad1, Smad5, and Smad9 (Song et al. 2018). Phosphorylated Smad1/5/9 can form a complex by interacting with Smad4, which can further activate or inhibit the expression of target genes (Rol et al., 2018). Given its interaction with BMPs, Smad1/5/9 might be related to the prolificacy of sheep.

Small Tail Han sheep (STH) and Sunite sheep (SNT) are two Chinese local sheep (Ovis aries) breeds with different estrous modes (year-round and seasonal, respectively. Both are known for their excellent meat production performance (Tang et al., 2018). Significant differences between the two sheep breeds in fecundity have resulted in increasing interest in the expression pattern of major prolificacy genes in these sheep.

BMPR1B, BMP15, GDF9, Smad1, Smad5, and Smad 9 are important in prolificacy. Many studies on the expression of these six genes in the tissues of ewes have been reported; however, no research has yet been reported about these genes in rams. To explore the potential role of these six genes in rams, we analyzed the tissue expression profile and the mRNA expression levels in eight prolificacy-related tissues between high fecundity sheep breed (STH) and low fecundity sheep breed (SNT) rams. Our study helps elucidate the genetic mechanism controlling high fecundity in rams.

\section{MATERIALS AND METHODS}

\section{Selection of experimental sheep and sample collection}

The 3 Small Tail Han rams and 3 Sunite rams were supplied by Yuncheng Breeding Sheep Farm (Yuncheng County, China) and Sheep and Goat Breeding Farm of Tianjin, Institute of Animal Sciences (Tianjin, China). All rams were healthy, approximately 2.5 years old, and were kept in a sheltered outdoor paddock and were provided with alfalfa hay and concentrate, with clear water available ad libitum. Eight tissues (brain, cerebellum, hypothalamus, pituitary, testis, epididymis, vas deferens, and adrenal gland) were collected from each animal. All tissues were snap-frozen in liquid nitrogen and then stored at $-80^{\circ} \mathrm{C}$ to be used for RNA extraction.

All experimental procedures mentioned in the present study were approved by the Science Research Department (in charge of animal welfare issue) of the Institute of Animal Sciences, Chinese Academy of Agricultural Sciences (IAS-CAAS) (Beijing, China). Ethical approval was provided by the animal ethics committee of IASCAAS (No. IASCAAS-AE-03, December 12, 2016).

\section{Total RNA extraction and cDNA synthesis}

Tissue RNA was extracted from the 8 tissues using a total RNA extraction kit for animal tissue (Tiangen, Beijing, China) and Trizol (Invitrogen Inc., Carlsbad, CA, USA) was used to dissolve the tissues (each tissue smashed, mixed, and 50-100 mg used for RNA extraction). The quantity and quality of total RNA were monitored using $1.5 \%$ agarose gel electrophoresis and ultraviolet spectrophotometry (UV-1201, Shimadzu, Kyoto, Japan), respectively. Then, the RNA was stored at $-80^{\circ} \mathrm{C}$ until use.

The first strand of cDNA was prepared following the instructions of the PrimeScript ${ }^{\mathrm{TM}}$ RT Reagent Kit (TaKaRa Bio Inc., Dalian, China). The reaction program was as follows: $37^{\circ} \mathrm{C}$ for $15 \mathrm{~min}$, followed by $85^{\circ} \mathrm{C}$ for $5 \mathrm{sec}$, with a total volume of $20 \mu \mathrm{L}$ that contained PrimeScript RT Enzyme $1.0 \mu \mathrm{L}$, Random 6 mers $1.0 \mu \mathrm{L}, 5 \times$ PrimeScript Buffer (for Real Time) $4.0 \mu \mathrm{L}$, total RNA $1.0 \mu \mathrm{L}$ and RNase-free $\mathrm{ddH}_{2} \mathrm{O} 13 \mu \mathrm{L}$. Prior to storage at $-80^{\circ} \mathrm{C}$, the standard working concentration of cDNA is $200 \mathrm{ng} / \mathrm{ul}$, the cDNA quality was evaluated by housekeeping gene $(R P L-$ 19) amplification, and then the reverse products were stored at $-20^{\circ} \mathrm{C}$ until use.

\section{RNA extraction and $C D N A$ synthesis}

Total RNA samples were analyzed using 1.5\% agarose gel electrophoresis $(\mathrm{U}=150 \mathrm{~V} ; \mathrm{I}=240 \mathrm{~mA})$. Three bands were detected (28S, 18S, and 5S) - the $28 \mathrm{~S}$ 
band was brighter than the $18 \mathrm{~S}$ band, and the $5 \mathrm{~S}$ band was unclear. The OD260 nm/OD280 $\mathrm{nm}$ ratios (1.8-2.0) of the RNA samples were all 1.9 to 2.0 , which showed that the extracted total RNA was of sufficient purity with no contamination or degradation. Therefore, these tissue RNAs were appropriate for use in the follow-up experiment.

\section{Primer design}

A total of 7 primers were designed using the Primer Premier (version 5.0, PREMIER Biosoft Co., Palo Alto, CA, USA) software to amplify different fragments of ovine BMPR1B, BMP15, GDF9, Smad1, Smad5, Smad9, and RPL-19 genes based on their assembled sequences in GenBank. All primers were synthesized by Beijing Tianyi Biotechnology Co., Ltd. (Beijing, China). The housekeeping gene (RPL-19, accession number: XM_012186026.1) was used as an internal control to normalize the threshold cycle $(\mathrm{Ct})$ values. The primers are detailed in Table I.

$q P C R$

Real-time polymerase chain reaction (PCR) amplification was performed in $20 \mu \mathrm{L}$ of reaction mixture that contained $10 \mu \mathrm{L}$ SYBR Premix EX Taq II (TaKaRa Bio Inc., Dalian, China), $0.4 \mu \mathrm{L}$ of each forward and reverse primer, $6.4 \mu \mathrm{L}$ RNase-Free $\mathrm{ddH}_{2} \mathrm{O}$, and $2 \mu \mathrm{L}$ cDNA. PCR amplification was performed in triplicate wells using the following conditions: initial denaturation at $95^{\circ} \mathrm{C}$ for $5 \mathrm{~min}$, followed by 40 cycles of $95^{\circ} \mathrm{C}$ for $10 \mathrm{sec}$, and $60^{\circ} \mathrm{C}$ for $30 \mathrm{sec}$. The dissociation curve was analyzed after amplification. A melting temperature $(\mathrm{Tm})$ peak at $85 \pm 0.8^{\circ} \mathrm{C}$ on the dissociation curve was used to determine the specificity of PCR amplification.
Data

The $2^{-\Delta \Delta C t}$ method (Guo et al. 2018) was used to process the real-time PCR results. Statistical analyses were carried out using SPSS 19.0 software (IBM, Armonk, NY, USA). The levels of gene expression were analyzed for significant differences with one-way analysis of variance (ANOVA), followed by the Fisher's least significant difference (LSD) test as a multiple comparison test. All experimental data are shown as mean \pm SEM. A probability of $p \leq 0.05$ was considered statistically significant, and a probability of $p \leq 0.01$ was considered to be extremely statistically significant.

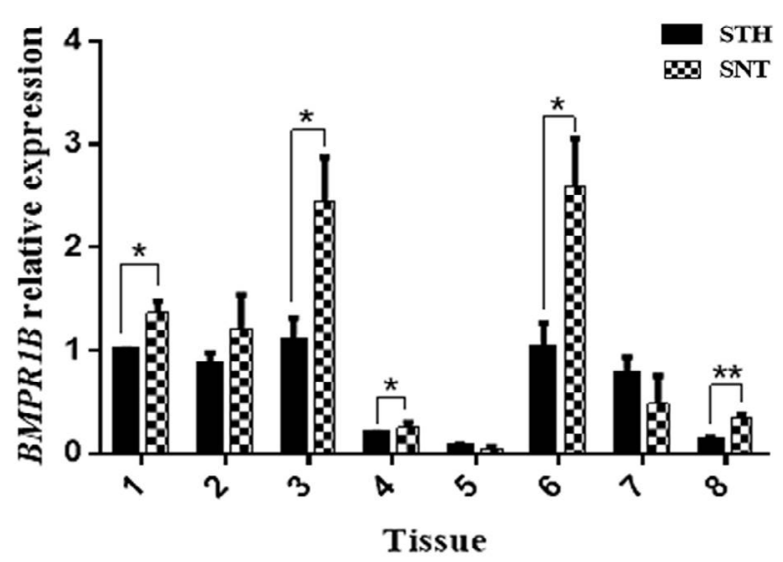

Fig. 1. Comparison of the expression of BMPR1B in eight tissues (Tissues 1-8: brain, cerebellum, hypothalamus, pituitary, testis, epididymis, vas deferens, and adrenal gland, respectively) between Small Tail Han sheep (STH) and Sunnite sheep (SNT). Means with different superscripts are significantly different. The significant results with a $p$-values lower than 0.01 and 0.05 are given two asterisks $(* *)$ and one asterisk $(*)$, respectively.

Table I.- Primers of studied genes.

\begin{tabular}{|c|c|c|c|c|}
\hline Gene Name & Primer sequence $\left(5^{\prime} \rightarrow 3^{\prime}\right)$ & Length (bp) & $\operatorname{Tm}\left({ }^{\circ} \mathrm{C}\right)$ & Accession No. \\
\hline BMPR1B & $\begin{array}{l}\text { F: 5'-TGACGGACCTATACACCACA-3' } \\
\text { R: 5'-GTACCGAGGTCTGGCTTCTT-3' }\end{array}$ & 121 & 60 & NM_001142888.2 \\
\hline$B M P 15$ & $\begin{array}{l}\text { F: 5'-TGTTGGGCAAAAGCTCTGGA-3' } \\
\text { R: 5'-GCCATGCCACCAGAACTCAA-3' }\end{array}$ & 106 & 60 & NM_001114767.1 \\
\hline GDF9 & $\begin{array}{l}\text { F: 5'-AACAGACGCCACCTCTACAA-3' } \\
\text { R: 5'-CACGATCCAGGTTAAACAGCA-3' }\end{array}$ & 124 & 60 & NM_001009431.1 \\
\hline Smad1 & $\begin{array}{l}\text { F: 5'-TGGTTCCAAGACACAGCGAATA-3' } \\
\text { R: 5'-GGTGTATCTGCTGGCATCTGAA-3 }\end{array}$ & 252 & 60 & XM_015101506.1 \\
\hline Smad5 & $\begin{array}{l}\text { F: 5'-GCACAGCCTTCTGGTTCA-3' } \\
\text { R: 5'-GGGTAGGGACTATTTGGAG-3' }\end{array}$ & 132 & 60 & XM_012115987.1 \\
\hline Smad9 & $\begin{array}{l}\text { F: 5'-CCAGCACTCAGATTTTCGGC-3' } \\
\text { R: 5'-GCACTCGGCATAGACCTCTC-3' }\end{array}$ & 147 & 60 & XM_015098108.1 \\
\hline RPL-19 & $\begin{array}{l}\text { F: 5'-ATCGCCAATGCCAACTC-3' } \\
\text { R: 5'-CCTTTCGCTTACCTATACC-3' }\end{array}$ & 154 & 60 & XM_012186026.1 \\
\hline
\end{tabular}




\section{RESULTS}

Expression levels of BMPR1B, BMP15, GDF9, Smad1, Smad5, and Smad9

The expression levels of BMPR1B, BMP15, GDF9, Smad1, Smad5, and Smad9 in eight tissues (brain, cerebellum, hypothalamus, pituitary, testis, epididymis, vas deferens, and adrenal gland) in both high fecundity breed Small Tail Han sheep and low fecundity breed Sunite sheep were measured by qPCR in this study.

As shown in Figure 1, BMPRIB is expressed in all tissues with the highest level in the epididymis, followed by the hypothalamus, brain, and cerebellum. The expression of $B M P R 1 B$ in the brain, hypothalamus, pituitary, epididymis, and adrenal gland is significantly higher in SNT than in STH $(p<0.01, p<0.05)$.

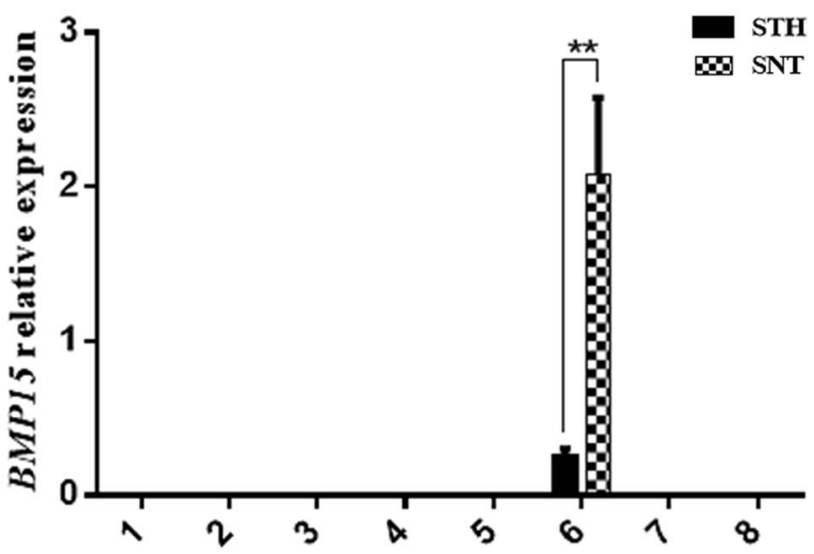

Tissue

Fig. 2. Comparison of the expression of BMP15 in eight tissues (Tissues 1-8: brain, cerebellum, hypothalamus, pituitary, testis, epididymis, vas deferens, and adrenal gland, respectively) between STH and SNT. Means with different superscripts are significantly different. The significant results with a $p$-values lower than 0.01 is given two asterisks $(* *)$.

As shown in Figure 2, $B M P 15$ is specifically expressed in the epididymis and the expression of BMP15 in the epididymis is significantly higher in SNT than in STH $(p<0.01)$.

As shown in Figure 3, GDF9 is expressed in all tissues with the highest level in the brain, followed by the testis, cerebellum, and hypothalamus. The expression of $G D F 9$ in the cerebellum and vas deferens is significantly higher in STH than in SNT $(p<0.05)$. The expression of GDF9 in the adrenal gland is significantly higher in SNT than in STH $(p<0.01)$.

As shown in Figure 4, Smadl 1 is expressed in all tissues with the highest level in the epididymis, followed by the cerebellum, brain, and hypothalamus. The expression of Smadl in the brain and adrenal gland is significantly higher in STH than in SNT $(p<0.05)$. The expression of Smadl in the vas deferens is significantly higher in SNT than in STH $(p<0.01)$.

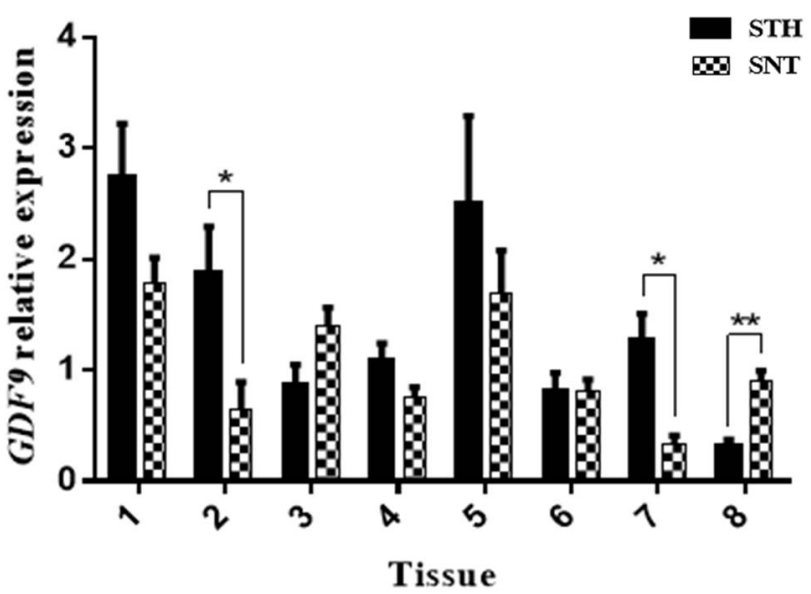

Fig. 3. Comparison of the expression of GDF9 in eight tissues (Tissues 1-8: brain, cerebellum, hypothalamus, pituitary, testis, epididymis, vas deferens, and adrenal gland, respectively) between STH and SNT. Means with different superscripts are significantly different. The significant results with a $p$-values lower than 0.01 and 0.05 are given two asterisks $(* *)$ and one asterisk $(*)$, respectively.

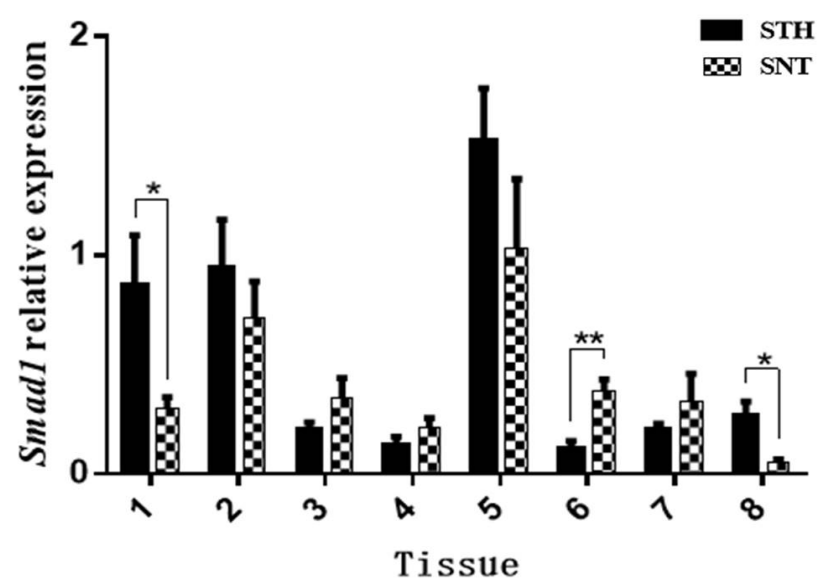

Fig. 4. Comparison of the expression of Smad1 in eight tissues (Tissues 1-8: brain, cerebellum, hypothalamus, pituitary, testis, epididymis, vas deferens, and adrenal gland, respectively) between STH and SNT. Means with different superscripts are significantly different. The significant results with a $p$-values lower than 0.01 and 0.05 are given two asterisks $(* *)$ and one asterisk $(*)$, respectively. 


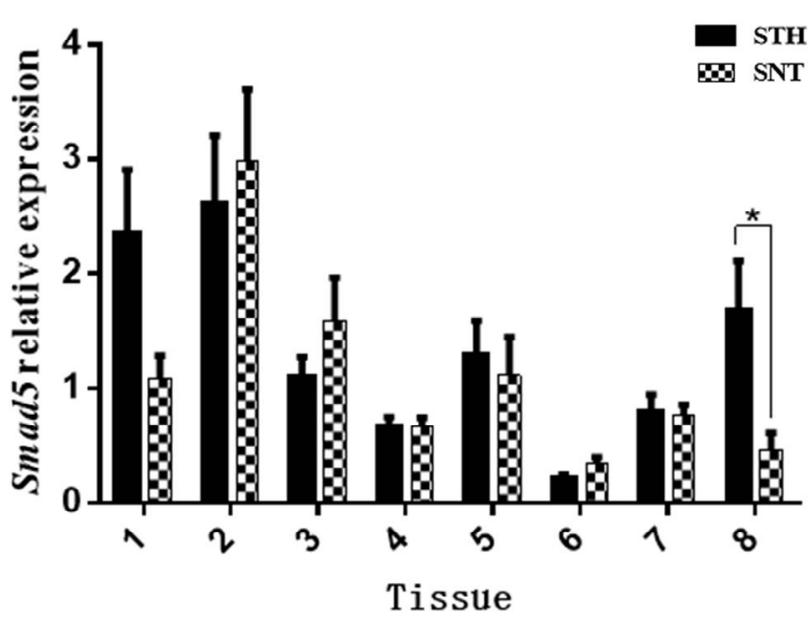

Fig. 5. Comparison of the expression of Smad5 in eight tissues (Tissues 1-8: brain, cerebellum, hypothalamus, pituitary, testis, epididymis, vas deferens, and adrenal gland, respectively) between STH and SNT. Means with different superscripts are significantly different. The significant results with a $p$-values lower than 0.05 is given one asterisk $(*)$.

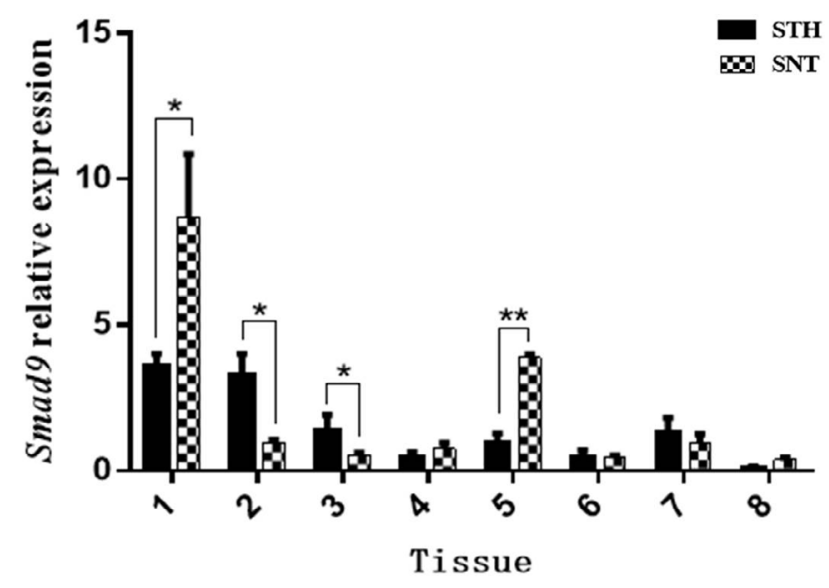

Fig. 6. Comparison of the expression of Smad9 in eight tissues (Tissues 1-8: brain, cerebellum, hypothalamus, pituitary, testis, epididymis, vas deferens, and adrenal gland, respectively) between STH and SNT. Means with different superscripts are significantly different. The significant results with a $p$-values lower than 0.01 and 0.05 are given two asterisks $(* *)$ and one asterisk $(*)$, respectively.

As shown in Figure 5, Smad5 is expressed in all tissues with the highest level in cerebellum, followed by the brain, hypothalamus, and adrenal gland. The expression of Smad5 in the adrenal gland is significantly higher in STH than in SNT $(p<0.05)$.

As shown in Figure 6, Smad9 is expressed in all tissues with the highest level in the brain, followed by the cerebellum, epididymis, and hypothalamus. The expression of Smad 9 in the brain and epididymis is significantly higher in SNT than in STH $(p<0.05, p<0.01$, respectively). The expression of $\operatorname{Smad} 9$ in the cerebellum and hypothalamus is significantly higher in STH than in SNT $(p<0.05)$.

\section{DISCUSSION}

\section{BMPR1B}

$B M P R 1 B$ ( $F e c B$ gene) is one of the major fecundity genes in female reproduction; however, not much is known about the reproductive role of the $B M P R 1 B$ gene in male reproduction. Previous reports have found that $B M P R 1 B$ belongs to the type I receptors of BMPs (Aquino et al., 2017; Kaivo-oja et al., 2006), which figures prominently in the directional migration and proliferation of primordial germ cells (PGCs) (Dudley et al., 2007; Okamura et al., 2005) and precursor cells of sperm (Hammoud et al., 2014; Larriba et al., 2018). Therefore, the BMPR1B gene has a certain impact on male reproduction.

Studies have found that $B M P R 1 B$ is widely expressed in the ovary, liver, hypothalamus, pituitary, uterus, heart, and muscle of mammals (Valdecantos et al., 2017; Goyal et al., 2017; Foroughinia et al., 2017). In ewes, $B M P R 1 B$ is highly expressed in the reproductive tissues and moderately expressed in the brain, skeletal muscle, and kidney (Ciller et al., 2016; Tang et al., 2018; Wilson et al., 2001). In this research, BMPRIB was found to be expressed in all selected tissues and highly expressed in the brain, cerebellum, hypothalamus, and epididymis, which indicated that BMPR1B may have a role in both ewe and ram reproduction.

The expression of BMPRIB in the brain, hypothalamus, pituitary, epididymis, and adrenal gland is significantly higher in SNT than in STH. This observation was different from a previous study comparing prolific and non-prolific ewes (Xu et al., 2010), in which ewes with high fecundity were reported to have a higher expression of $B M P R 1 B$ in the reproductive tissues, which implies that ram may have a different regulation mechanism in reproduction when compared to ewe. Considering the function of $B M P R 1 B$ in the proliferation of PGCs, it seems plausible that $B M P R 1 B$ may have a certain inhibitory effect on ram reproduction. Of course, further studies should be performed deeply to investigate the relationship between $B M P R 1 B$ and ram reproduction.

\section{BMP15}

$B M P 15$ is an important regulator of male germ stem cell (mGSC) proliferation and differentiation (Liu et al., 2018). Hu et al. (2017) reported that over-expression of 
$B M P 15$ in goat mGSCs leads to the increased expression level of c-Kit, a gene that promotes spermatogonial differentiation and the proliferation of mGSCs. Thus, BMP15 is an important candidate gene in male fertility.

In 1998, Dube et al. (1998) explored the expression of $B M P 15$ in several tissues, including ovary and testis in mice, and found that $B M P 15$ is specifically expressed in the ovary. The expression of BMP15 in goats (Silva et al., 2005) and pigs (Li et al., 2008) is similar to that in mice. In contrast, Aaltonen et al. (1999) reported the expression of BMP15 in the testis and ovary in humans. Similarly, Pennetier et al. (2004) reported the expression of BMP15 in the testis and ovary in cattle. This study suggested that BMP15 is specifically expressed in the epididymis in rams. One potential explanation is that the differences in the genetic models led to these results.

It is known that $B M P 15$ exerts its biological effects by initially interacting with a type II receptors of BMPs, which results in the activation and phosphorylation of BMPR1B (Moore et al., 2003). We compared the expression level of $B M P 15$ and $B M P R 1 B$, the expression of BMP15 and BMPR1B in the epididymis in SNT was found to be significantly higher than in STH which implies that the expression level of BMP15 and BMPR1B may be negatively correlated with the fecundity of rams.

\section{GDF9}

For a long time, GDF9 was considered to be specifically expressed in the ovaries of animals, until Fitzpatrick et al. (1998) reported the expression of GDF9 in non-ovarian tissues including the testis, brain, pituitary and bone marrow. Earlier, the GDF9 expression was detected in the testis in rats, mice, humans, cattle (Tang et al., 2017), alpacas (Guo et al., 2013) and cats (Zhao et al., 2011). To our knowledge, no research on the expression of GDF9 in rams has ever been reported. In the present study, GDF9 was detected in all 8 tissues in rams, which implies that it plays a role in promoting the differentiation of many tissues. The highest expression of GDF9 in the epididymis further confirmed that $G D F 9$ is associated with the epididymal function.

Because numerous studies revealed that $G D F 9$ has promoting effects on genetic and cellular signaling levels and the mitosis of germ cells (Tang et al., 2013; He et al., 2012), we compared the expression level of GDF9 in the testis, epididymis, and vas deferens between two sheep breeds. We found no significant difference between the expression level of GDF9 in the testis and epididymis of SNT and STH, but the expression level of GDF9 in the vas deferens of STH is significantly higher than in SNT. Our findings are in agreement with Tang et al. (2017) who found exogenous GDF9 significantly promoted Sertoli cells (SCs) proliferation and inhibited the apoptosis of SCs which suggested GDF9 to have a supporting role for the maintenance of spermatogenesis. Therefore, we concluded that the prolificacy of ram might be due to the high expression level of the GDF9 gene.

Smad

Smad1/5/9 is widely expressed in mammals, especially in the brain and hypothalamus-pituitarygonadal (HPG) axis (Wang et al., 2018a, b; Ohyama et al., 2015). The present study found that $S m a d 1 / 5 / 9$ is detectable in eight tissues of rams; meanwhile, the expression level of Smad1/5/9 in the brain, cerebellum, and HPG axis is higher than in other tissues, which is consistent with our expectation.

BMP type I receptors are transphosphorylated by type II receptors, resulting in cascades of Smad signaling (Aquino et al., 2017). Shi et al. (2016) found that the deletion of $B M P R 1 B$ leads to an increased phosphorylation level and decreased expression level of Smad1/5/9 in male mice. To explore the expression pattern of $B M P R 1 B$ in rams, we compared the expression level of $B M P R 1 B$ and Smad1/5/9. We surprisingly found that the expression level of BMPRIB in the brain, epididymis, and adrenal gland is significantly higher in SNT than in STH; meanwhile, the expression level of Smad1/5 in the brain and adrenal gland was higher in STH than in SNT. The results show that BMPR1B signaling may be involved in some of those mechanisms in the brain and adrenal gland of rams; however, the expression level of Smad1 in the epididymis is significantly higher in SNT than in STH. We speculate that BMPRIB may have a certain inhibitory effect on the spermatogenesis of rams; however, the degree of the function of $B M P R I B$ in rams remains to be investigated.

Studies have demonstrated that the BMP/ Smad signaling pathway may be associated with the spermatogenesis process (Itman et al., 2010). Research on mice (Mendis et al., 2011) and rats (Chan et al., 2017) may provide an insight into the synergistic effect of BMP15 and Smad1/5/9 in male animals: the expression level of Smad1/5/9 is positively regulated by BMP signaling (Katakawa et al., 2016). Additionally, we compared the expression level of BMP15 and Smad1/5/9. The expression of BMP15 and Smadl in the epididymis of SNT is significantly higher than in STH, but there is no significant difference between the expression of Smad5 and Smad9 in the epididymis of two sheep breeds. We provide evidence that the BMP/Smad signaling pathway may be associated with the spermatogenesis process in rams to some degree. Further research is necessary to draw conclusions. 


\section{CONCLUSIONS}

In conclusion, we found that BMPR1B, GDF9, Smad1, Smad5, and Smad9 are expressed in all selected tissues and are highly expressed in the epididymis, whereas $B M P 15$ is specifically expressed in the epididymis, which indicates that they may play important roles in the ovine epididymis and promote spermatogenesis. Our findings of ovine BMPR1B, BMP15, GDF9, Smad1, Smad5, and Smad 9 will help to further understand their expression and function, and may contribute to exploring their role in the ram reproduction system. This is the first study of the six genes tissue expression pattern in rams.

\section{ACKNOWLEDGEMENTS}

This research was funded by National Natural Science Foundation of China (31772580, 31872333), Earmarked Fund for China Agriculture Research System (CARS-38), Agricultural Science and Technology Innovation Program of China (ASTIP-IAS13), China Agricultural Scientific Research Outstanding Talents and Their Innovative Teams Program, China High-level Talents Special Support Plan Scientific and Technological Innovation Leading Talents Program (W02020274), Tianjin Agricultural Science and Technology Achievements Transformation and Popularization Program (201704020), The Projects of Domesticated Animals Platform of the Ministry of Science, Key Research and Development Plan (modern agriculture) in Jiangsu Province (BE2018354), Major new varieties of agricultural projects in Jiangsu Province (PZCZ201739), Jiangsu Agricultural Science and Technology Innovation Fund (CX(18)2003), The Project Funded by the Priority Academic Program Development of Jiangsu Higher Education Institutions, Major projects of Natural Science Research of Colleges and Universities in Jiangsu Province (17KJA230001), The Project of six peak of talents of Jiangsu Province of China and Postgraduate Research and Practice Innovation Program of Jiangsu Province (SJCX18_0804).

Statement of conflicts of interest

All authors declare no conflicts of interest.

\section{REFERENCES}

Aaltonen, J., Laitinen, M.P., Vuojolainen, K., Jaatinen, R., Horelli, K.N., Seppä, L., Louhio, H., Tuuri, T., Sjöberg, J. and Bützow, R., 1999. Human growth differentiation factor $9(G D F-9)$ and its novel homolog $G D F-9 B$ are expressed in oocytes during early folliculogenesis. J. clin. Endocrinol.
Metabol., 84: 2744-2750. https://doi.org/10.1210/ jc.84.8.2744

Alam, M.H., Lee, J. and Miyano, T., 2018. GDF9 and BMP15 induce development of antrum-like structures by bovine granulosa cells without oocytes. J. Reprod. Devel., 64: 423-431. https://doi. org/10.1262/jrd.2018-078

Aquino, M.R., Artigas, N., Gámez, B., Rosa, J.L. and Ventura, F., 2017. Extracellular calcium promotes bone formation from bone marrow mesenchymal stem cells by amplifying the effects of $B M P-2$ on SMAD signalling. PLoS One, 12: e178158. https:// doi.org/10.1371/journal.pone.0178158

Belli, M. and Shimasaki, S., 2018. Molecular aspects and clinical relevance of GDF9 and BMP15 in ovarian function. Vitam. Horm, 107: 317-348. https://doi.org/10.1016/bs.vh.2017.12.003

Bodin, L., Di, P.E., Fabre, S., Bontoux, M., Monget, P., Persani, L. and Mulsant, P., 2007. A novel mutation in the bone morphogenetic protein 15 gene causing defective protein secretion is associated with both increased ovulation rate and sterility in Lacaune sheep. Endocrinology, 148: 393-400. https://doi. org/10.1210/en.2006-0764

Braun, V., Mahren, S. and Ogierman, M., 2003. Regulation of the FecI-type ECF sigma factor by transmembrane signalling. Curr. Opin. Microbiol., 6: $\quad 173-180 . \quad$ https://doi.org/10.1016/S13695274(03)00022-5

Ciller, I.M., Palanisamy, S.K., Ciller, U.A. and Mcfarlane, J.R., 2016. Postnatal expression of bone morphogenetic proteins and their receptors in the mouse testis. Physiol. Res., 65: 673-682.

Chan, K.H., Galuska, S.P., Kudipudi, P.K., Riaz, M.A., Loveland, K.L. and Konrad, L., 2017. Signaling by TGF-betas in tubule cultures of adult rat testis. Am. J. Transl. Res., 9: 1173-1182.

Crawford, J.L., Heath, D.A., Reader, K.L., Quirke, L.D., Hudson, N.L., Juengel, J.L. and McNatty, K.P., 2011. Oocytes in sheep homozygous for a mutation in bone morphogenetic protein receptor $1 \mathrm{~B}$ express lower mRNA levels of bone morphogenetic protein 15 but not growth differentiation factor 9 . Reproduction, 142: 53-61. https://doi.org/10.1530/ REP-10-0485

Dube, J.L., Wang, P., Elvin, J., Lyons, K.M., Celeste, A.J. and Matzuk, M.M., 1998. The bone morphogenetic protein 15 gene is $\mathrm{X}$-linked and expressed in oocytes. Mol. Endocrinol., 12: 1809-1817. https:// doi.org/10.1210/mend.12.12.0206

Dudley, B.M., Runyan, C., Takeuchi, Y., Schaible, K. and Molyneaux, K., 2007. BMP signaling 
regulates PGC numbers and motility in organ culture. Mechan. Dev., 124: 68-77. https://doi. org/10.1016/j.mod.2006.09.005

El-Seedy, A.S., Hashem, N.M., El-Azrak, K.M., Nour, E.A., Ramadan, T.A., Taha, T.A. and Salem, M.H., 2017. Genetic screening of $\mathrm{FecB}, \mathrm{FecX}(\mathrm{G})$ and FecX(I) mutations and their linkage with litter size in Barki and Rahmani sheep breeds. Reprod. Domest. Anim., 52: 1133-1137. https://doi. org/10.1111/rda.13002

Fitzpatrick, S.L., Sindoni, D.M., Shughrue, P.J., Lane, M.V., Merchenthaler, I.J. and Frail, D.E., 1998. Expression of growth differentiation factor-9 messenger ribonucleic acid in ovarian and nonovarian rodent and human tissues. Endocrinology, 139: 2571-2578. https://doi. org/10.1210/en.139.5.2571

Foroughinia, G., Fazileh, A. and Eghbalsaied, S., 2017. Expression of genes involved in BMP and estrogen signaling and AMPK production can be important factors affecting total number of antral follicles in ewes. Theriogenology, 91: 36-43. https://doi. org/10.1016/j.theriogenology.2016.12.023

Galloway, S.M., McNatty, K.P., Cambridge, L.M., Laitinen, M.P., Juengel, J.L., Jokiranta, T.S., McLaren, R.J., Luiro, K., Dodds, K.G. and Montgomery, G.W., 2000. Mutations in an oocytederived growth factor gene (BMP15) cause increased ovulation rate and infecundity in a dosage-sensitive manner. Nat. Genet., 25: 279-283. https://doi.org/10.1038/77033

Goyal, S., Aggarwal, J., Dubey, P.K., Mishra, B.P., Ghalsasi, P., Nimbkar, C., Joshi, B.K. and Kataria, R.S., 2017. Expression analysis of genes associated with prolificacy in $F e c B$ carrier and noncarrier Indian sheep. Anim. Biotechnol., 28: 220-227. https://doi.org/10.1080/10495398.2016.1262869

Guo, Q.Y., Gao, Z.Z., Zhao, L., He, J.P. and Dong, C.S., 2013. Expression of growth differentiation factor 9 (GDF9), $A L K 5$, and claudin-11 in adult alpaca testis. Acta Histochem., 115: 16-21. https://doi. org/10.1016/j.acthis.2012.02.007

Guo, X.F., Wang, X.Y., Liang, B.M., Di, R., Liu, Q.Y., Hu, W.P., He, X.Y., Zhang, J.L., Zhang, X.S. and Chu, M.X., 2018. Molecular cloning of the B4GALNT2 gene and its single nucleotide polymorphisms association with litter size in Small Tail Han sheep. Animals, 8: 160. https://doi. org/10.3390/ani8100160

Hammoud, S.S., Low, D.H., Yi, C., Carrell, D.T., Guccione, E. and Cairns, B.R., 2014. Chromatin and transcription transitions of mammalian adult germline stem cells and spermatogenesis. Cell Stem Cell, 15: 239-253. https://doi.org/10.1016/j. stem.2014.04.006

Hanrahan, J.P., Gregan, S.M., Mulsant, P., Mullen, M., Davis, G.H., Powell, R. and Galloway, S.M., 2004. Mutations in the genes for oocyte-derived growth factors GDF9 and BMP15 are associated with both increased ovulation rate and sterility in Cambridge and Belclare sheep (Ovis aries). Biol. Reprod., 70: 900-909. https://doi.org/10.1095/ biolreprod.103.023093

He, Z., Wu, Y., Xie, J., Wang, T., Zhang, L. and Zhang, W., 2012. Growth differentiation factor 9 (GDF9) was localized in the female as well as male germ cells in a protogynous hermaphroditic teleost fish, ricefield eel Monopterus albus. Gen. Comp. Endocrinol., 178: 355-362. https://doi. org/10.1016/j.ygcen.2012.06.016

$\mathrm{Hu}, \mathrm{S} ., 2017$. The effects of $\mathrm{BMP} 15$ gene on proliferation and differentiation of cashmere goats mGSCs. Northwest A\&F University: Yangling, China.

Itman, C. and Loveland, K.L., 2010. SMAD expression in the testis: An insight into BMP regulation of spermatogenesis. Devel. Dynam., 237: 97-111. https://doi.org/10.1002/dvdy.21401

Julie, D., Stéphane, F., Julien, S., Raffaella, R., Hélène, G., Luca, P., Gwenola, T.K., Philippe, M., Zuzanna, N. and Wioleta, D., 2013. Genome-wide association studies identify two novelbmp 15 mutations responsible for an atypical hyperprolificacy phenotype in sheep. PLoS Genet., 9: e1003482. https://doi.org/10.1371/journal.pgen.1003482

Katakawa, Y., Funaba, M. and Murakami, M., 2016. Smad8/9 is regulated through the BMP pathway. J. Cell. Biochem., 117: 1788-1796. https://doi. org $/ 10.1002 / \mathrm{jcb} .25478$

Kaivo-oja, N., Jeffery, L.A., Ritvos, O. and Mottershead, D.G., 2006. Smad signalling in the ovary. Reprod. Biol. Endocrinol., 4: 21. https://doi. org/10.1186/1477-7827-4-21

Larriba, E., Rial, E. and Del, M.J., 2018. The landscape of mitochondrial small non-coding RNAs in the PGCs of male mice, spermatogonia, gametes and in zygotes. BMC Genom., 19: 634. https://doi. org/10.1186/s12864-018-5020-3

Lassoued, N., Benkhlil, Z., Woloszyn, F., Rejeb, A., Aouina, M., Rekik, M., Fabre, S. and Romdhani, S.B., 2017. Fec $\mathrm{X}^{\mathrm{Bar}}$ a novel BMP15 mutation responsible for prolificacy and female sterility in Tunisian barbarine sheep. BMC Genet., 18: 43. https://doi.org/10.1186/s12863-017-0510-x

Li, H.K., Kuo, T.Y., Yang, H.S., Chen, L.R., Li, S.S. and 
Huang, H.W., 2008. Differential gene expression of bone morphogenetic protein 15 and growth differentiation factor 9 during in vitro maturation of porcine oocytes and early embryos. Anim. Reprod. Sci., 103: 312-322. https://doi.org/10.1016/j. anireprosci.2006.12.017

Lin, X., Dai, Y., Xu, W., Shi, L., Jin, X., Li, C., Zhou, F., Pan, Y., Zhang, Y. and Lin, X., 2018. Hypoxia promotes ectopic adhesion ability of endometrial stromal cells via TGF- $\beta 1 /$ Smad signalling in endometriosis. Endocrinology, 159: 1630-1641. https://doi.org/10.1210/en.2017-03227

Liu, C., Yuan, B., Chen, H., Xu, M., Sun, X., Xu, J., Gao, Y., Chen, C., Jiang, H. and Zhang, J., 2018. Effects of MiR-375-BMPR2 as a key factor downstream of BMP15/GDF9 on the Smad1/5/8 and Smad2/3 signaling pathways. Cell Physiol. Biochem., 46: 213-225. https://doi.org/10.1159/000488424

Mendis, S.H., Meachem, S.J., Sarraj, M.A. and Loveland, K.L., 2011. Activin A balances Sertoli and germ cell proliferation in the fetal mouse testis. Biol. Reprod., 84: 379-391. https://doi. org/10.1095/biolreprod.110.086231

Monteagudo, L.V., Ponz, R., Tejedor, M.T., Laviña, A. and Sierra, I., 2009. A 17 bp deletion in the Bone Morphogenetic Protein 15 (BMP15) gene is associated to increased prolificacy in the Rasa Aragonesa sheep breed. Anim. Reprod. Sci., 110: 139-146. https://doi.org/10.1016/j. anireprosci.2008.01.005

Montgomery, G.W., Lord, E.A., Penty, J.M., Dodds, K.G., Broad, T.E., Cambridge, L., Sunden, S.L., Stone, R.T. and Crawford, A.M., 1994. The Booroola fecundity $(\mathrm{FecB})$ gene maps to sheep chromosome 6. Genomics, 22: 148-153. https:// doi.org/10.1006/geno.1994.1355

Moore, R.K., Otsuka, F. and Shimasaki, S., 2002. Molecular basis of bone morphogenetic protein-15 signaling in granulosa cells. J. biol. Chem., 278: 304-310. https://doi.org/10.1074/jbc.M207362200

Mullen, M.P. and Hanrahan, J.P., 2014. Direct evidence on the contribution of a missense mutation in GDF9 to variation in ovulation rate of Finnsheep. PLoS One, 9: e95251. https://doi.org/10.1371/journal. pone. 0095251

Nicol, L., Bishop, S.C., Pong, W.R., Bendixen, C., Holm, L., Rhind, S.M. and McNeilly, A.S., 2009. Homozygosity for a single base-pair mutation in the oocyte-specific GDF9 gene results in sterility in Thoka sheep. Reproduction, 138: 921-933. https:// doi.org/10.1530/REP-09-0193

Ohyama, K., Ohta, M., Hosaka, Y.Z., Tanabe, Y.,
Ohyama, T. and Yamano, Y., 2015. Expression of anti-Mullerian hormone and its type II receptor in germ cells of maturing rat testis. Endocrinol. J., 62: 997-1006. https://doi.org/10.1507/endocrj.EJ150370

Okamura, D., Hayashi, K. and Matsui, Y., 2005. Mouse epiblasts change responsiveness to BMP4 signal required for PGC formation through functions of extraembryonic ectoderm. Mol. Reprod. Devel., 70: 20-29. https://doi.org/10.1002/mrd.20136

Pan, Z., Wang, X., Di, R., Liu, Q.Y., Hu, W.P., Cao, X.H., Guo, X.F., He, X.Y., Lv, S.J., Li, F.K. and Chu, M.X., 2018. A 5-methylcytosine site of growth differentiation factor $9(G D F 9)$ gene affects its tissue-specific expression in sheep. Animals, 8: 200. https://doi.org/10.3390/ani8110200

Pennetier, S., Uzbekova, S., Perreau, C., Papillier, P., Mermillod, P. and Dalbiès-Tran, R., 2004. Spatiotemporal expression of the germ cell marker genes MATER, ZAR1, GDF9, BMP15 and VASA in adult bovine tissues, oocytes, and preimplantation embryos. Biol. Reprod., 71: 1359-1366. https://doi. org/10.1095/biolreprod.104.030288

Rol, N., Kurakula, K.B., Happé, C., Bogaard, H.J. and Goumans, M.J., 2018. TGF-beta and BMPR2 signaling in PAH: Two black sheep in one family. Int. J. mol. Sci., 19: 2585. https://doi.org/10.3390/ ijms 19092585

Shafieiyan, Z., Mohammadi, G., Jolodarzadeh, A. and Amiri, S., 2013. No mutations of FecB and FecG(H) in Iranian Lory sheep. Vet. Res. Forum, 4: 265-268.

Shokrollahi, B. and Morammazi, S., 2018. Polymorphism of GDF9 and BMPR $1 B$ genes and their association with litter size in Markhoz goats. Reprod. Domest. Anim., 53: 971-978. https://doi. org/10.1111/rda.13196

Shi, C., Iura, A., Terajima, M., Liu, F., Lyons, K., Pan, H., Zhang, H., Yamauchi, M., Mishina, Y. and Sun, H., 2016. Deletion of BMP receptor type IB decreased bone mass in association with compromised osteoblastic differentiation of bone marrow mesenchymal progenitors. Scient. Rep., 6: 24256. https://doi.org/10.1038/srep24256

Silva, B.D., Castro, E.A., Souza, C.J., Paiva, S.R., Sartori, R., Franco, M.M., Azevedo, H.C., Silva, T.A., Vieira, A.M. and Neves, J.P., 2011. A new polymorphism in the growth and differentiation factor $9(G D F 9)$ gene is associated with increased ovulation rate and prolificacy in homozygous sheep. Anim. Genet., 42: 89-92. https://doi.org/10.1111/ j.1365-2052.2010.02078.x 
Silva, J.R., Hurk, R., Tol, H.T., Roelen, B.A. and Figueiredo, J.R., 2005. Expression of growth differentiation factor $9(G D F 9)$, bonemorphogenetic protein 15 (BMP15), and BMP receptors in the ovaries of goats. Mol. Reprod. Devel., 70: 11-19. https://doi.org/10.1002/mrd.20127

Song, W., Ghosh, A.C., Cheng, D. and Perrimon, N., 2018. Endocrine regulation of energy balance by drosophila TGF-beta/Activins. Bioessays, 40: e1800044. https://doi.org/10.1002/bies.201800044

Souza, C.J., McNeilly, A.S., Benavides, M.V., Melo, E.O. and Moraes, J.C., 2014. Mutation in the protease cleavage site of $G D F 9$ increases ovulation rate and litter size in heterozygous ewes and causes infecundity in homozygous ewes. Anim. Genet., 45 : 732-739. https://doi.org/10.1111/age.12190

Tang, J., Hu, W., Di, R., Liu, Q.Y., Wang, X.Y., Zhang, X.S., Zhang, J.L. and Chu, M.X., 2018. Expression analysis of the prolific candidate genes, $B M P R 1 B$, $B M P 15$, and GDF9 in Small Tail Han ewes with three fecundity (FecB gene) genotypes. Animals, 8: 166. https://doi.org/10.3390/ani8100166

Tang, K.Q., Yang, W.C., Zhang, X.X. and Yang, L.G., 2013. Effects of polymorphisms in the bovine growth differentiation factor 9 gene on sperm quality in Holstein bulls. Genet. mol. Res., 12: 2189-2195. https://doi.org/10.4238/2013.July.4.1

Tang, K.Q., Wang, L., Jin, Y., Yang, W. and Yang, L., 2017. GDF9 affects the development and tight junction functions of immature bovine Sertoli cells. Reprod. Domest. Anim., 52: 640-648. https://doi. org/10.1111/rda.12960

Våge, D.I., Husdal, M., Kent, M.P., Klemetsdal, G. and Boman, I.A., 2013. A missense mutation in growth differentiation factor $9(G D F 9)$ is strongly associated with litter size in sheep. BMC Genet., 14: 1. https://doi.org/10.1186/1471-2156-14-1

Valdecantos, P.A., Bravo, Miana, R.D., García, E.V., García, D.C., Roldán, O.M. and Miceli, D.C., 2017. Expression of bone morphogenetic protein receptors in bovine oviductal epithelial cells: Evidence of autocrine BMP signaling. Anim.
Reprod. Sci., 185: 89-96. https://doi.org/10.1016/j. anireprosci.2017.08.006

Wang, L., Ding, Q., Zhao, L., Pan, Y., Song, Z., Qin, Y. and Yan, X., 2018. Decreased BMP-7 and $p$-Smad1/5/8 expression, and increased levels of gremlin in hepatocellular carcinoma. Oncol. Lett., 16: 2113-2118. https://doi.org/10.3892/ ol.2018.8918

Wang, S., Hu, S., Wang, J., Liu, Y., Zhao, R., Tong, M., Cui, H., Wu, N. and Chen, X., 2018. Conditioned medium from bone marrow-derived mesenchymal stem cells inhibits vascular calcification through blockade of the BMP2-Smad1/5/8 signaling pathway. Stem Cell Res., 9: 160. https://doi. org/10.1186/s13287-018-0894-1

Wang, X., Yang, Q., Wang, K., Yan, H., Pan, C., Chen, H., Liu, J., Zhu, H., Qu, L. and Lan, X., 2018. Two strongly linked single nucleotide polymorphisms (Q320P and V397I) in GDF9 gene are associated with litter size in cashmere goats. Theriogenology, 125: 115-121. https://doi.org/10.1016/j. theriogenology.2018.10.013

Wilson, T., Wu, X.Y., Juengel, J.L., Ross, I.K., Lumsden, J.M., Lord, E.A., Dodds, K.G., Walling, G.A., McEwan, J.C. and O'Connell, A.R., 2001. Highly prolific Booroola sheep have a mutation in the intracellular kinase domain of bone morphogenetic protein IB receptor $(A L K-\sigma)$ that is expressed in both oocytes and granulosa cells. Biol. Reprod., 64: 1225-1235. https://doi.org/10.1095/ biolreprod64.4.1225

Xu, Y.F., Li, E.L., Han, Y.D., Chen, L. and Xie, Z.A., 2010. Differential expression of mRNAs encoding BMP/SMAD pathway molecules in antral follicles of high- and low-fecundity $\mathrm{Hu}$ sheep. Anim. Reprod. Sci., 120: 47-55. https://doi.org/10.1016/j. anireprosci.2010.02.009

Zhao, L., He, J., Guo, Q., Wen, X., Zhang, X. and Dong, C., 2011. Expression of growth differentiation factor $9(G D F 9)$ and its receptor in adult cat testis. Acta Histochem., 113: 771-776. https://doi. org/10.1016/j.acthis.2010.11.005 